\begin{tabular}{c|c|c|}
\cline { 3 - 3 } CRITICAL & $\begin{array}{l}\text { Western Ghats } \\
\text { PARTNERSHIP FUND }\end{array}$ \\
\cline { 3 - 4 } & Special Series \\
\hline
\end{tabular}

\title{
Length-weight relationship and condition factor of an endemic stone sucker, Garra gotyla stenorhynchus (Jerdon, 1849) from two opposite flowing rivers in southern Western Ghats
}

\author{
Fibin Baby ${ }^{1}$, Josin Tharian ${ }^{2}$, Kurian Mathew Abraham ${ }^{3}$, M.R. Ramprasanth ${ }^{4}$, Anvar Ali ${ }^{5}$ \& \\ Rajeev Raghavan ${ }^{6}$
}

1,2,4,5,6 Conservation Research Group, St. Albert's College, Kochi, Kerala 682018, India

${ }^{2}$ Department of Zoology and Environmental Science, St. John's College, Anchal, Kerala 691306, India

${ }^{3}$ Postgraduate and Research Department of Zoology, Mar Thoma College, Tiruvalla, Kerala 689103, India

${ }^{6}$ Durrell Institute of Conservation and Ecology, University of Kent, Canterbury CT2 7NZ, United Kingdom

Email: ${ }^{1}$ fibinaqua@gmail.com, ${ }^{2}$ josinc@gmail.com, ${ }^{3}$ kurianma@gmail.com, ${ }^{4}$ ramprasanthmanasam@gmail.com,

${ }^{5}$ anvaraliif@gmail.com, ${ }^{6}$ rajeevraq@hotmail.com (corresponding author)

The mathematical relationship between length and weight of fishes (LWR) is a practical index suitable for understanding their survival, growth, maturity, reproduction, and general well being (Le Cren 1951). Information on LWR also allows for morphological comparisons among species, or among populations

Date of publication (online): 26 June 2011

Date of publication (print): 26 June 2011

ISSN $0974-7907$ (online) | 0974-7893 (print)

Editor: Neelesh Dahanukar

Manuscript details:

Ms \# 02535

Received 03 August 2010

Final revised received 30 April 2011

Finally accepted 12 May 2011

Citation: Baby, F., J. Tharian, K.M. Abraham, M.R. Ramprasanth, A. A \& R. Raghavan (2011). Length-weight relationship and condition facto of an endemic stone sucker, Garra gotyla stenorhynchus (Jerdon, 1849) from two opposite flowing rivers in southern Western Ghats. Journal of Threatened Taxa 3(6): 1851-1855.

Copyright: (C) Fibin Baby, Josin Tharian, Kurian Mathew Abraham, M.R. Ramprasanth, Anvar Ali \& Rajeev Raghavan 2011. Creative Commons Attribution 3.0 Unported License. JoTT allows unrestricted use of this article in any medium for non-profit purposes, reproduction and distribution by providing adequate credit to the authors and the source of publication.

Acknowledgements: Our study was funded by a grant from the Critical Ecosystem Partnership Fund (CEPF) through the Western Ghats Program. We are grateful to K.K. Srivastava (Chief Wildlife Warden, Department of Forests and Wildlife, Government of Kerala) for permits, and to Unnikrishnan (DFO, Nilambur South); V.P. Jayprakash (Range Officer, Karulai, Nilambur) and John Mathew (Assistant Wildlife Warden, Silent Valley National Park) for their help with the logistics. We also thank our colleagues at the conservation Research Group (CRG), St. Albert's College (Kochi), Ratheesh, Prasobh, Simmy Solomon and Shylaja Menon for their help and assistance and to Benno Pereira for the facilities provided

\section{OPEN ACCESS I FREE DOWNLOAD (C) (1) (4)}

Abstract: Length weight relationship (LWR) and condition factor were studied in Nilgiri Garra, Garra gotyla stenorhynchus (Jerdon), from the rivers Chaliyar and Bhavani flowing through the Western Ghats Biodiversity Hotspot. The regression equation for LWR of the Nilgiri Garra from Chaliyar River was estimated as $\log W t=2.920 \log L-1.854$, while those from Bhavani River as $\log W t=2.594 \log L-1.538$. Although, the ' $b$ ' value observed from west flowing Chaliyar River (2.920) was higher than that from east flowing Bhavani River (2.594), they were statistically insignificant. Similarly, the Condition Factor (K) was higher in Bhavani populations (2.177) compared to Chaliyar (2.087), but were also statistically insignificant. The results indicated that populations of G. gotyla stenorhynchus in Chaliyar River followed an isometric like growth pattern with 'b' values close to cubic law. However local populations of the same species in Bhavani River are under stress as indicated by comparatively lower 'b values. This difference in ' $b$ ' value between the two river populations may be due to the differences in physical habitat features of the locations from where they were sampled, including altitude, physical habitat features, water quality and their combined influence on the availability of food materials as well as stock/ population differences and yet to be identified stressors.

Keywords: Condition factor, Garra gotyla stenorhynchus, length weight relationship, Western Ghats.

of the same species from different habitats and/or regions (Moutopoulos \& Stergiou 2002). Although estimating LWR is considered to be a regular research work of fisheries scientists (Froese 2006), such data

\footnotetext{
This article forms part of a special series on the Western Ghats of India, disseminating the results of work supported by the Critical Ecosystem Partnership Fund (CEPF), a joint initiative of I'Agence Française de Développement, Conservation International, the Global Environment Facility, the Government of Japan, the MacArthur Foundation and the World Bank. A fundamental goal of CEPF is to ensure civil society is engaged in biodiversity conservation. Implementation of the CEPF investment program in the Western Ghats is led and coordinated by the Ashoka Trust for Research in Ecology and the Environment (ATREE).
} 
are currently available only for a restricted number of species (Kulbicki et al. 2005), especially in the Western Ghats. The same paucity of data also applies for the information on Condition Factor (K), which compares the well being of a fish based on the hypothesis that heavier fish of a given length are in a better condition (Bagenal \& Tesch 1978).

The Nilgiri Garra Garra gotyla stenorhynchus (Jerdon, 1849) is an endemic stone sucker found in the streams of southern and central Western Ghats (Dahanukar et al. 2004). G. gotyla stenorhynchus is collected and exported to the international aquarium pet trade under the name Pincer-faced Algae Eater (Raghavan 2010), and is also eaten by tribes and local communities residing along the river basins where they occur (Daniels 2002). They are generally caught along with other stream fishes, often using destructive fishing practices including dynamiting and poisoning.

As with many endemic freshwater fish species of the Western Ghats, there is very little information on the various aspects of biology and population status of $G$. gotyla stenorhynchus in its native range. The only previous study on the LWR of this species (Kurup et al. 2002) is rather vague and does not mention the sampling locations. An attempt is therefore made to determine and compare the LWR and the condition factor of this endemic stone sucker from two major rivers in the southern Western Ghats.

\section{Methods}

Samples of $G$. gotyla stenorhynchus for the present study originated from two rivers - Bhavani

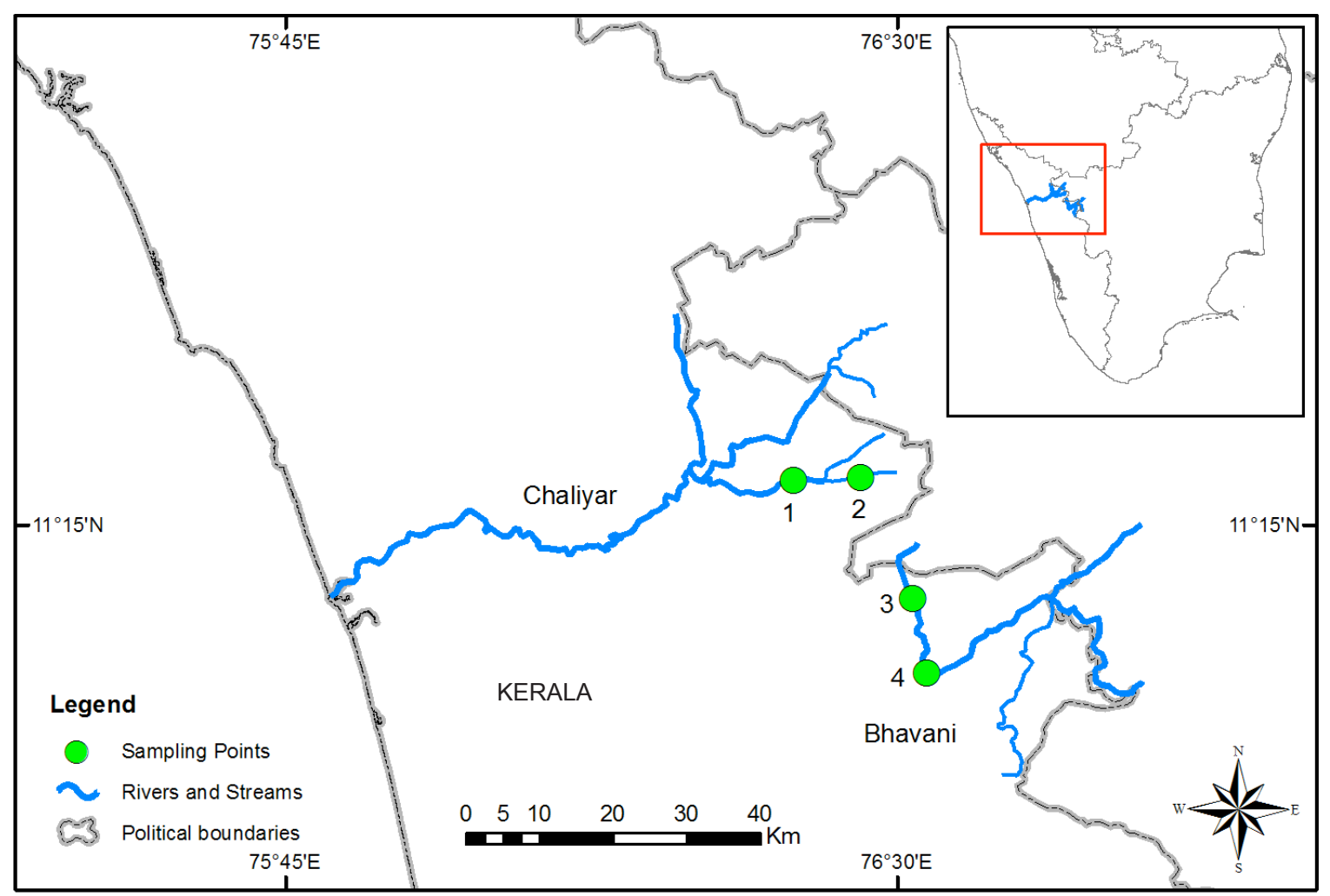

Figure 1. Sampling sites in Bhavani River and Chaliyar River

Table 1. Altitude and physical habitat features of the sampling sites

\begin{tabular}{|c|l|l|c|l|l|}
\hline No & \multicolumn{1}{|c|}{ Site } & \multicolumn{1}{|c|}{ River } & Altitude $(\mathbf{m})$ & Microhabitat & Substrate Type \\
\hline 1 & Kanjirakkadavu & Chaliyar & 96 & Pool riffle & Sand \& pebble \\
\hline 2 & Paanapuzha & Chaliyar & 196 & Pool riffle & Sand \& cobble \\
\hline 3 & Thudikki & Bhavani & 1038 & Cascade & Bed Rock \\
\hline 4 & Mukkali & Bhavani & 540 & Rapid & Cobble \\
\hline
\end{tabular}


(east flowing) and Chaliyar (west flowing) (Fig. 1) of Western Ghats. Random samples were collected from various sites in the Bhavani drainage located in the Silent Valley National Park, and Chaliyar drainage located in the New Amarambalam Reserve Forest (Table 1). To avoid sampling bias, fish were captured by the same type of gear (backpack electro-shocker) and during the same season (between March and June 2010). Fish samples $(n=104 ; 60$ from Bhavani and 44 from Chaliyar) were measured for their total length (TL) and wet body weight (WT) using digital calipers $(0.01 \mathrm{~mm})$, and weight scale with $0.001 \mathrm{~g}$ accuracy at the field and released back into the stream.

The LWR was subsequently determined using the equation $\mathrm{W}=\mathrm{aL}^{\mathrm{b}}$ (Pauly 1984) and logarithmically transformed into $\log \mathrm{W}=\log \mathrm{a}+\mathrm{b} \log \mathrm{L}$ where $\mathrm{W}$ is the weight of the fish in gram and $\mathrm{L}$ is the total length of the fish measured in millimeter. The parameters ' $a$ '

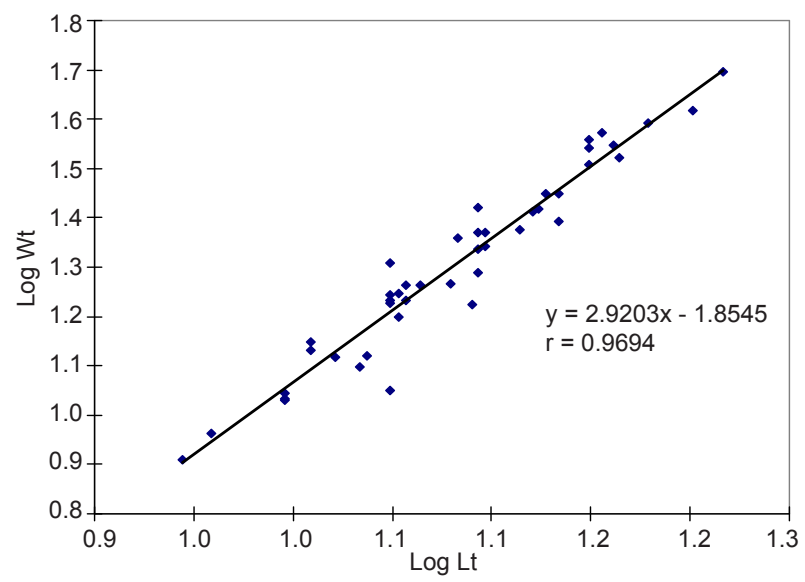

Figure 2. Length weight relationship of Garra gotyla stenorhynchus from Chaliyar River

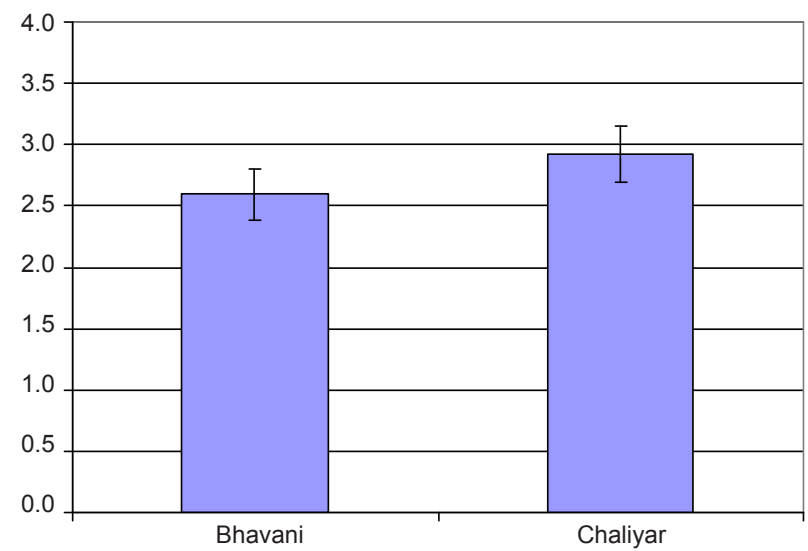

Figure 4. Comparison of ' $b$ ' values of length weight relationship of G. gotyla stenorhynchus from two rivers (proportionality constant) and ' $b$ ' (exponent) of the LWR were estimated by least square regression (Zar 1999). The null hypothesis that $b=3$ was tested using $t$ test as described by Zar (1999; pp.342). To test whether the power $b$, calculated as a slope of the log-log plot for weight and length, was different for two rivers, we used t test as described by Zar (1999; pp. 362). Fulton's Condition factor $(\mathrm{K})$ was determined using the formula $\mathrm{K}=100 \mathrm{~W} / \mathrm{L}^{3}$ following Tesch (1971), where $\mathrm{W}$ is the weight of the fish and $\mathrm{L}$ is the length of the fish.

The use of electro-fishing as the sampling method meant that the total fish population of the area could be sampled, with minimum sampling errors, and without causing damage to the wildr stock. Size range of specimens from Bhavani River was from $6.10 \mathrm{~mm}$ to $18.30 \mathrm{~mm}$, while those from Chaliyar River were $8.80 \mathrm{~mm}$ to $16.47 \mathrm{~mm}$.

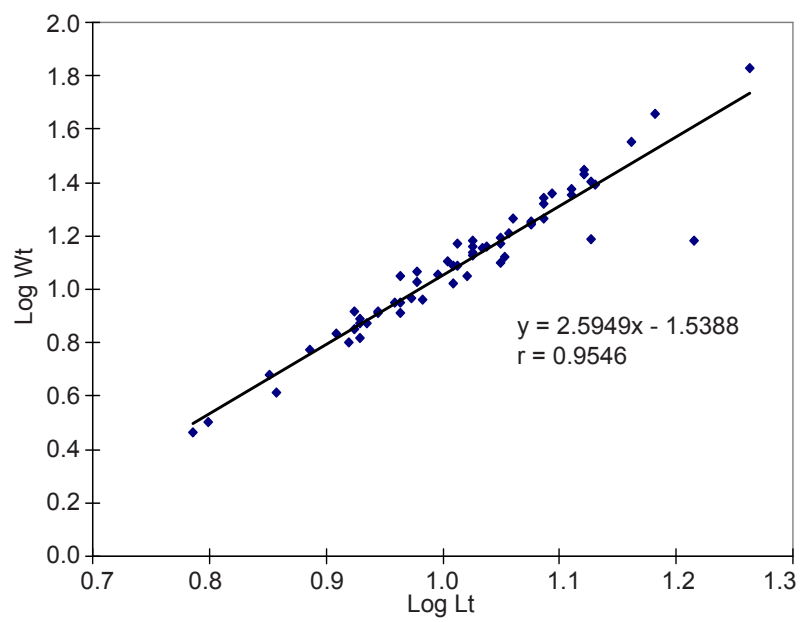

Figure 3. Length weight relationship of Garra gotyla stenorhynchus from Bhavani River

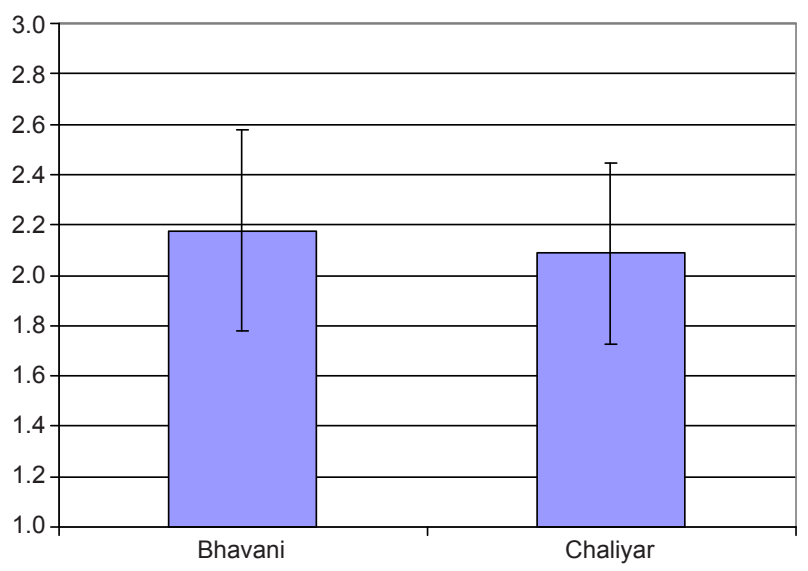

Figure 5. Comparison of condition factor values of $G$. gotyla stenorhynchus from two rivers 


\section{Results}

The LWR of G. gotyla stenorhynchus from Chaliyar River in the form of a regression equation was estimated as $\log \mathrm{Wt}=2.920 \mathrm{Log} \mathrm{L}-1.854$ (Fig. 2), while those from Bhavani River as Log Wt $=2.594$ Log L - 1.538 (Fig. 3). The 'b' value of Chaliyar River (2.9203, SE = 0.1141) was not significantly different from the cubic value as expected by isometry $(\mathrm{t}=-0.6987, \mathrm{df}=42, \mathrm{p}=0.4886)$. However, the ' $\mathrm{b}$ ' value of Bhavani River (2.5949, $\mathrm{SE}=0.1063$ ) was significantly different from the expected cubic value $(\mathrm{t}=-3.8096, \mathrm{df}=58, \mathrm{p}=0.0003)$ indicating that the species does not grow isometrically in Bhavani River. Even though the 'b' value of G. gotyla stenorhynchus obtained from Chaliyar River was slightly higher than that obtained from Bhavani River (Fig. 4) the difference was not significant $(\mathrm{t}=-1.7583, \mathrm{df}=100, \mathrm{p}=0.0818)$. Although the condition factor (K) (Fig. 5) of G. gotyla stenorhynchus from Bhavani River showed higher values (2.177) than from Chaliyar (2.087), these were statistically insignificant $(\mathrm{t}=0.339 ; \mathrm{p}>0.05)$.

\section{Discussion}

Exponent of the arithmetic form and the slope of the regression line in the logarithmic form, ' $b$ ' is the most important parameter in a LWR (Froese 2006). If ' $b=3$ ', then small specimens in the samples under consideration have the same form and condition as large specimens. If ' $b>3$ ', then large specimens have increased in height or width more than in length, either as the result of a notable ontogenetic change in body shape with size, which is rare, or because most large specimens in the sample were thicker than small specimens, which is common. Conversely, if ' $b$ $<3$ ', then large specimens have changed their body shape to become more elongated or small specimens were in better nutritional condition at the time of sampling (Froese 2006). Differences in 'b' values and its variations from the ideal ' 3 ' can also arise due to variations in habitat, gonadal maturity and preservation techniques among others (Tesch 1971; Wooton 1990). Recent evidence also indicates that LWR is also subjected to evolutionary selection (Kharat et al. 2008). In the present study, we compared the LWR and condition factor of $G$. gotyla stenorhynchus from two different rivers of the Western Ghats, flowing in opposite directions - Bhavani (east flowing) and Chaliyar (west flowing).
In the present study, 'b' value of $G$. gotyla stenorhynchus from Bhavani River was lower than (but not statistically significant) that from Chaliyar River. One of the reasons for this difference could be the specific habitat preference of the species. $G$. gotyla stenorhynchus may be more suited to the pool riffle microhabitats in lower elevation zones (90-200 $\mathrm{m})$, when compared to the rapid and cascade type of microhabitat in the higher altitudes (500-1100 m). The energy expenditure of the species for mobility could also be higher in the high altitude cascade and rapid microhabitats when compared to the milder pool riffle habitats in low elevation zones.

There are also possibilities that an unknown stressor exists in Bhavani River as is evident from the previous reports of skeletal deformities in freshwater fish species (Raj et al. 2004). However, we did not observe any such morphological changes in the samples of $G$. gotyla stenorhynchus from this river.

It is known that the regression coefficients for flattened fishes including those within the genus Garra are lower than the other species (Martin-Smith 1996). This may reflect inherently higher variability in the body shape, greater sexual dimorphism, than for heavy-bodied fishes, seasonal changes in gonad development or some other undetermined factor (Martin-Smith 1996). A significant deviation from the cube law and an ' $r$ ' value of 0.88 has been earlier reported in G. gotyla stenorhynchus (Kurup et al. 2002). However, the authors did not provide any information on the ' $b$ ' value, and also as to from where the samples were collected, thereby making it impossible to make a detailed comparison. The same authors also reported that $G$. surendranathanii had an ' $r$ ' value of 0.73 and also showed deviation from the cube law (without mentioning the ' $b$ ' value), and $G$. periyarensis had an ' $r$ ' value of 0.96 , and that the 'b' value (value not mentioned) did not significantly deviate from the ideal value of ' 3 ' (Kurup et al. 2002). Both $G$. surendranathanii and $G$. periyarensis are endemic to the Kerala region of the Western Ghats. To the best of our knowledge, there is no other study on the LWR of G. gotyla stenorhynchus. The 'b' values obtained in the present study (2.92 and 2.59) are also higher than those obtained on two Southeast Asian species of stone suckers, G. borneensis (2.45) (MartinSmith et al 1996) and G. cambodgiensis (Mazlan et al. 2007). Although Jha et al. (2005) studied the LWR 
of G. gotyla gotyla from Nepal, the authors have not provided any ' $b$ ' value in their results, making a comparison difficult.

Condition factor is a useful index for the monitoring of feeding intensity, age, and growth rates in fish (Oni et al. 1983). It is strongly influenced by both biotic and abiotic environmental conditions and can therefore be used as an index to assess the status of the aquatic ecosystem in which fish live (Anene 2005). Although the condition factor of G. gotyla stenorhynchus from Bhavani River was higher than from Chaliyar River (2.087), these were statistically insignificant. The $\mathrm{K}$ values of $G$. gotyla stenorhynchus are however lower than those obtained for G. cambodgiensis from northern Malaysia (Mazlan et al. 2007).

The results of the present study indicate that populations of G. gotyla stenorhynchus in Chaliyar River follow an isometric like growth pattern with ' $b$ ' values close to cubic law and that local populations of the same species in Bhavani River have a lower ' $b$ value, deviating from the ideal ' 3 '. However, there was no significant difference in the condition factor of the species between the two rivers.

\section{REFERENCES}

Anene, A. (2005). Condition factor of four Cichlid species of a man-made lake in Imo State, Southeastern Nigeria. Turkish Journal of Fisheries and Aquatic Sciences 5: 43-47.

Raj, J.A., S. Seetharaman \& M.A. Haniffa (2004). Skeletal deformities in a few freshwater fishes from Bhavani River, Tamil Nadu. Zoos' Print Journal 19(9): 1628-1629.

Bagenal, T.B. \& F.W. Tesch (1978). Age and growth, pp. 101136. In: Begenal, T. (ed.). Methods for Assessment of Fish Production in Fresh Waters-3 $3^{\text {rd }}$ Edition. IBP Handbook No. 3, Blackwell Science Publications, Oxford, 365pp.

Dahanukar, N., R. Raut \& A. Bhat (2004). Distribution, endemism and threat status of freshwater fishes in the Western Ghats of India. Journal of Biogeography 31: 123136.

Daniels, R.J.R. (2002). Freshwater Fishes of Peninsular India. Universities Press (India) Private Limited, 288pp.

Froese, R. (2006). Cube law, condition factor and weight-length relationships: history, meta-analysis and recommendations. Journal of Applied Ichthyology 22: 241-253.

Jha, B.R., H. Waidbache, S. Sharma \& M. Straif (2005). Length weight relationship of Sucker head, Garra gotyla gotyla (Gray, 1830) in different rivers of Nepal and the influence of Monsoon. International Journal of Environmental Science and Technology 2(2): 147-153.
Jerdon, T.C. (1849). On the fresh-water fishes of southern India. Madras Journal of Literature and Science 15(2): 302-346.

Kharat, S.S., Y.K. Khillare \& N. Dahanukar (2008). Allometric scaling in growth and reproduction of a freshwater loach Nemacheilus mooreh (Sykes, 1839). Electronic Journal of Ichthyology 4(1): 8-17.

Kulbicki, M., N. Guillemot \& M. Amand (2005). A general approach to length-weight relationships for new caledonian lagoon fishes. Cybium 29: 235-252.

Kurup, B.M., K.V. Radhakrishnan \& C.J. Euphrasia (2002). Length weight relationship of some of the endangered and critically endangered freshwater fishes of Kerala part of the Western Ghats. In: Life History Traits Of Freshwater Fish Population For Its Utilization In Conservation. National Bureau of Fish Genetic Resources (NBGFR)-National Agricultural Technology Program (NATP) Publication No 4. Lucknow, India, AA2 1-4.

Le Cren, E.D. (1951). The length weight relationship and seasonal cycle in gonad weight and condition in the perch (Perca fluviatilis). Journal of Animal Ecology 20: 210239.

Martin-Smith, K.M. (1996). Length/weight relationships of fishes in a diverse tropical fresh-water community, Sabah, Malaysia. Journal of Fish Biology 49: 731-734.

Mazlan, A.G., A. Samat, A. Amirrudin \& R. Balagurunathan (2007). Aspects on the biology of Garra cambodgiensis and Mystacoleucus marginatus (Cyprinidae) from Ulu Dungun, Terengganu. Malaysian Applied Biology Journal 36(1): 67-72.

Moutopoulos, D.K \& K.I. Stergiou (2002). Length-weight and length-length relationships of fish species from the Aegean Sea (Greece). Journal of Applied Ichthyology 18: 200-203.

Oni, S.K., J. Y. Olayemi \& J. D. Adegboye (1983). Comparative physiology of three ecologically distinct freshwater fishes, Alestes nurse Ruppell, Synodontis schall Bloch and S. schneider and Tilapia zilli Gervais. Journal of Fish Biology 22: 105-109.

Pauly, D. (1984). Fish Population Dynamics in Tropical Waters: A Manual for Use With Programmable Calculator. ICLARM Studies and Reviews, Manila, Philippines, 8: 325pp.

Raghavan, R. (2010). Ornamental fisheries and trade in Kerala, pp. 169-187. In: Sonnenschein, L. \& A. Benziger (eds.). Conservation of Fishes in Kerala, India. World Aquarium, St. Louis, 294pp.

Tesch, F.W. (1971). Age and growth, pp. 98-130. In: Ricker, W.E. (ed.). Methods for Assessment of Fish Production in Fresh Waters. Blackwell Scientific Publications, Oxford.

Wooton, R.J. (1990). Ecology of Teleost Fishes. Chapman and Hall, London, 404pp.

Zar, J.H. (1999). Biostatistical Analysis. Fourth edition. Pearson Education, India, 929pp. 